Araştırma Makalesi - Research Article

\title{
Thermal Behaviors of AS Series Magnesium Alloys
}

\section{AS Serisi Magnezyum Alaşımlarının Termal Davranışları}

\begin{abstract}
Birol Akyüz ${ }^{1 *}$
Geliş / Received: 20/12/2020

Revize / Revised: 29/04/2021

Kabul / Accepted: 30/04/2021

ABSTRACT

This paper presents experimental investigation on thermal behaviors (thermal diffusivity and thermal conductivity) of AS series cast magnesium alloys. The effects of the changing in $\mathrm{Al}$ content (from 1 to $9 \mathrm{Al}$ and constantly $1 \mathrm{Si}$, wt.\%) in the alloys on thermal properties, density, and hardness were comparatively analyzed. It was observed that intermetallic phases $\left(\mathrm{Mg}_{17} \mathrm{Al}_{12}\right.$ and $\left.\mathrm{Mg}_{2} \mathrm{Si}\right)$ found in the microstructure of the alloys have an effect on thermal diffusivity, thermal conductivity, density and also hardness. The thermal properties of the alloys were decrease with increasing $\mathrm{Al}$ content in the alloy. The thermal properties of the alloys were increase with increasing temperature (the temperature range from $25^{\circ} \mathrm{C}$ to $400^{\circ} \mathrm{C}$ ). The highest thermal diffusivity was measured on AS2 1 alloy and the lowest thermal diffusivity were observed on AS91 alloy.
\end{abstract}

Keywords- AS Series Magnesium Alloys, Thermal Diffusivity, Thermal Conductivity, Density, Hardness

ÖZ

Bu makale, AS serisi döküm magnezyum alaşımlarının ısıl davranışları (1sıl yayılma ve 1sıl iletkenlik) üzerine deneysel bir araştırma sunmaktadır. Alaşımlardaki Al içeriğindeki değişimin (1-9 Al ve 1 Si sabit, ağırlıkça \%) ısıl özellikler, yoğunluk ve sertlik üzerindeki etkileri karşılaştırmalı olarak analiz edilmiştir. Alaşımların mikroyapısında bulunan intermetalik fazların $\left(\mathrm{Mg}_{17} \mathrm{Al}_{12}\right.$ ve $\left.\mathrm{Mg}_{2} \mathrm{Si}\right)$ 1sıl yayınım, 1sıl iletkenlik, yoğunluk ve ayrıca sertlik üzerine etkisi olduğu görülmüştür. Alaşımın ısıl özellikleri, alaşımdaki Al içeriği arttıkça azalmıştır. Alaşımların termal özellikleri artan sıcaklıkla artmıştır (sıcaklık değişimi $25^{\circ} \mathrm{C}-400{ }^{\circ} \mathrm{C}$ arası). En yüksek termal yayılma AS21 alaşımında ölçülmüştür ve en düşük termal yayılma AS91 alaşımında gözlenmiştir.

Anahtar Kelimeler- AS Serisi Magnezyum Alaşımları, Termal Yayılma, Termal İletkenlik, Yoğunluk, Sertlik

1*Sorumlu yazar iletișim: birol.akyuz@bilecik.edu.tr (https://orcid.org/0000-0003-4462-3288) Makine Mühendisliği Bölümü, Bilecik Şeyh Edebali Üniversitesi, Mühendislik Fakültesi, Bilecik, Türkiye 


\begin{tabular}{|c|c|c|}
\hline & $\begin{array}{l}\text { BŞEÜ Fen Bilimleri Dergisi } \\
8(1), 109-115,2021\end{array}$ & $\begin{array}{r}\text { BSEU Journal of Science } \\
\text { https://doi.org/10.35193/bseufbd. } 843874\end{array}$ \\
\hline $\begin{array}{l}\text { BLLECEIK SEYH EDEBALI } \\
\text { UNIVERSITESI }\end{array}$ & & 2458-7575 (https://dergipark.org.tr/tr/pub/bseufbd) \\
\hline
\end{tabular}

\section{INTRODUCTION}

Today's magnesium alloys, owing to their high specific strength and low density, weight-resistance and weight-hardness characteristics, excellent casting properties and mechanical properties, biodegradable properties, are usually used as lightweight structural materials in various applications, such as automobile and aerospace parts, electrical, telecommunication and microelectronics appliances, materials-handling and medical implants (i.e. stents, orthopedic, spinal and dental implants) [1-10]. Notably, in automotive and aerospace industry (i.e AS21, AS41, AM50), the using of magnesium alloys are important goal to decrease fuel consumption and so, air pollutants such as SOx, CO2, and NOx emissions [1-3,10-11].

In the literature, the largely used $\mathrm{Mg}$ alloys are classified as AZ, AS, AM and AJ series Mg alloys [6,1030]. Among many magnesium alloys developed, i.e. AS21, AS41, AM20, AM60, AZ31, AJ62 and AZ91 are the most widely used commercial alloys because of their microstructure, mechanical, wear and castability properties [6-30]. Magnesium products/parts are generally produced by machining (turning, milling etc.) after the casting process [3,10,13-17]. It is realizable a high speed machining for magnesium alloys; but, there are refer that with an increase in cutting speed, there may be critical flank build-up (FBU) due to adhesion between the cutting tool surface and the workpiece as well as chip ignition and tool wear [3,10,13-17,23-27]. There are studies in the literature discussing chip ignition and burning issues, which arise during machining of magnesium alloys. These studies examine the effects of processing parameters on chip ignition and burning [3,10,13-17,23-27]. In the literature, there are some studies on FBU and chip formation (chip morphology) on cutting tool surfaces depending on characteristics and processing parameters of magnesium alloys [3,10,13-17,23-27]. In previous works of the author, it was reported that FBU increases due to the friction on cutting tool surface during machining, and it was emphasized that the cutting forces increase and also chip formation and surface roughness change [3,10,13-17,2327]. Cutting tool and workpiece surface temperature, exposure time to heat, dislocation density and thermal properties of magnesium play a crucial role on chip ignition, chip formation and the oxidation mechanism $[10,23-$ 27].

In the literature, there are limited studies on thermal properties/behaviors of magnesium alloys. We found the study of Lee et al. [28] and Rudajevová and Lukáč [29] who studied AZ31, AZ61 and AM20, AS21 magnesium alloys as a function of $\mathrm{Al}$ content by comparing thermal properties/behaviors of these alloys. On the other hand, the comparison may be arguable since AZ, AS and AM alloys have different microstructures and alloy compositions. Therefore, we investigated effect of $\mathrm{Al}$ alloying additions systematically (from 1 to $9 \mathrm{Al}$ and $1 \mathrm{Si}$ constantly, wt.\%) to AS series cast magnesium alloys on its thermal properties/behaviors (thermal diffusivity, thermal conductivity, density and also hardness). For this reason, this study is important and distinctive for literature.

\section{EXPERIMENTAL PROCEDURE}

AS series $\mathrm{Mg}$ alloys used in this study were obtained by casting into metal molds after being melted in atmosphere controlled melting furnaces (under $\mathrm{CO}_{2}+\mathrm{SF}_{6}$ shielding gas medium). Casting or manufacturing of magnesium alloys was detailed by Akyüz [10,23-26] and Ünal [6] in their previous studies. Furthermore, details of preparation and processing stages of tests performed in this study, details of sample standards and test procedures (i.e. microstructure samples polishing, etching process and etching solutions) were explained in previous studies of the author [10,23-26]. Microstructure and XRD analyses were performed on each sample. Xray diffraction (XRD) analyses (Panalytical-Empyrean) were carried out under $\mathrm{Cu} \mathrm{K} \alpha$ radiation with an incidence beam angle of $2^{\circ}$. Hardness tests (Shimadzu HMV-2) were carried out (on each sample at ten measurements). The alloy compositions of test samples of AS series cast Mg alloys (Spectrolab M8 Optical Emission Spectrometry) are presented in Table 1. 
Table 1. Alloy composition of the samples (wt.\%).

\begin{tabular}{cccccc}
\hline Alloys & Al & Si & Zn & Fe & Mg \\
\hline AS11 & 1.1 & 1.1 & 0.1 & 0.02 & Rest \\
AS21 & 2.1 & 1.1 & 0.1 & 0.02 & Rest \\
AS41 & 4.1 & 1.1 & 0.1 & 0.02 & Rest \\
AS61 & 6.1 & 1.1 & 0.1 & 0.02 & Rest \\
AS91 & 9.1 & 1.1 & 0.1 & 0.02 & Rest \\
\hline & ("A " refers to the Al and "S" refers to Si content of the alloy.) &
\end{tabular}

The density of the alloys was measured (at least ten measurements) by the Archimedes method (He gas atmosphere, under $22 \mathrm{psi} / 1.5$ pressure, in $10 \mathrm{~cm}^{3}$ specimen container, AccuPycII 1340 Pycnometer, Micromeritics Instrument Corp. U.S.A.). Density of these alloys was determined by averaging ten measurement values. The thermal diffusivity of AS series cast magnesium alloys were measured. The thermal diffusivity measurement was carried out the temperature range from $25^{\circ} \mathrm{C}$ to $400^{\circ} \mathrm{C}$ (with a Netzsch model LFA 457 Laser Flash Device and Atmosphere $\mathrm{N}_{2}$, gas flow $100.00 \mathrm{ml} / \mathrm{min}$, under isothermal conditions more than $10 \mathrm{~min}$.). Chunming at.al. (2013) explained a comprehensive description the test sample standards and test procedures or process of the magnesium alloys [30]. The following equation was used in calculating the thermal conductivity [30,31]:

$$
\lambda=\alpha \rho \mathrm{c}_{\mathrm{p}}
$$

Where $\lambda$ is the thermal conductivity $\left(\lambda: \mathrm{W} \cdot \mathrm{m}^{-1} \mathrm{~K}^{-1}\right), \alpha$ is the thermal diffusivity $\left(\alpha: \mathrm{mm}^{2} \mathrm{~s}^{-1}\right), \rho$ is the density $\left(\rho: \mathrm{g} \mathrm{cm}^{-3}\right)$ and $c_{p}$ is the specific heat capacity $\left(c_{p}: \mathrm{J} \mathrm{g}^{-1} \mathrm{~K}^{-1}\right.$ accepted as fixed).

Lee et al. 2013 [28] reported that there is no significant difference in the specific heat capacities of AZ31 and AZ61 as the aluminum quantities are quite similar. In their study, the specific heat capacity of magnesium $\left(1.0241 \mathrm{~J} \mathrm{~g} \mathrm{~g}^{-1} \mathrm{~K}^{-1}\right)$ and aluminum $\left(0.9025 \mathrm{~J} \mathrm{~g}^{-1} \mathrm{~K}^{-1}\right)$ showed very little difference at room temperature [28]. Therefore, changes in the specific heat capacities of magnesium alloys caused by addition of aluminum in differing proportions are not significant. In this study, the specific heat capacity $\left(c_{p}\right)$ is accepted as fixed.

\section{RESULTS AND DISCUSSION}

\section{A. Microstructure, XRD Pattern and Hardness}

The microstructure images (optical light microscopy-OM) and XRD patterns of the alloys are seen on Figure 1 and Figure 2, respectively. The microstructure of these alloys is made up of $\alpha$-Mg matrix and intermetallic phases $\left(\mathrm{Mg}_{17} \mathrm{Al}_{12}\right.$ and $\mathrm{Mg}_{2} \mathrm{Si}$ ) (Figure 2). It is seen that the $\mathrm{Mg}_{2} \mathrm{Si}$ intermetallic phase in the microstructure is in the form of Chinese scripts and $\mathrm{Mg}_{17} \mathrm{Al}_{12}$ intermetallic phase ranges roughly along the grain boundaries (network formation). The morphologic structure of these alloys are consistent with the literature [5,6,8,9,11,12,23-25]. In the literature, it was indicated that the formation and location of intermetallic phases were due to changes in the solidification behavior of the melt by alloy addition (i.e. $\mathrm{Zn}, \mathrm{Si}, \mathrm{Mn}, \mathrm{Sr}$ etc.) $[5,6,8,9,11,12,23-25]$. When the microstructure images of the AS91 alloy (seen in Figure 1e.) were examined, it was observed that the intermetallic phases in the alloy $\left(\mathrm{Mg}_{17} \mathrm{Al}_{12}\right.$ and $\mathrm{Mg}_{2} \mathrm{Si}$ ) were more evident and distributed within the structure depending on the variation of alloy components $(9 \mathrm{Al}$, wt.\%).

The hardness tests results obtained from the alloys are given in Figure 3. The mean hardness values of alloys were estimated as $41.8 \mathrm{HV}_{10}$ in the AS11 alloy, $48.6 \mathrm{HV}_{10}$ in the AS21, 51.6 $\mathrm{HV}_{10}$ in the AS41 alloy, 54.7 $\mathrm{HV}_{10}$ in the AS61 and $62.4 \mathrm{HV}_{10}$ in the AS91 alloy, respectively. The highest hardness was obtained from the AS91 alloy. 


\begin{tabular}{|c|c|c|}
\hline & $\begin{array}{l}\text { BŞEÜ Fen Bilimleri Dergisi } \\
8(1), 109-115,2021\end{array}$ & $\begin{array}{r}\text { BSEU Journal of Science } \\
\text { https://doi.org/10.35193/bseufbd.843874 }\end{array}$ \\
\hline $\begin{array}{l}\text { BILECIK SEYY EDEBALL } \\
\text { ONIVERSITESI }\end{array}$ & & 2458-7575 (https://dergipark.org.tr/tr/pub/bseufbd) \\
\hline
\end{tabular}
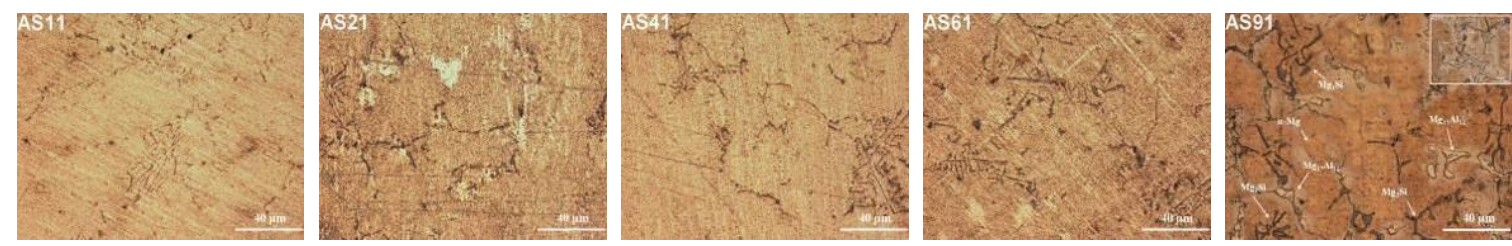

Figure 1. Microstructure of the alloys.

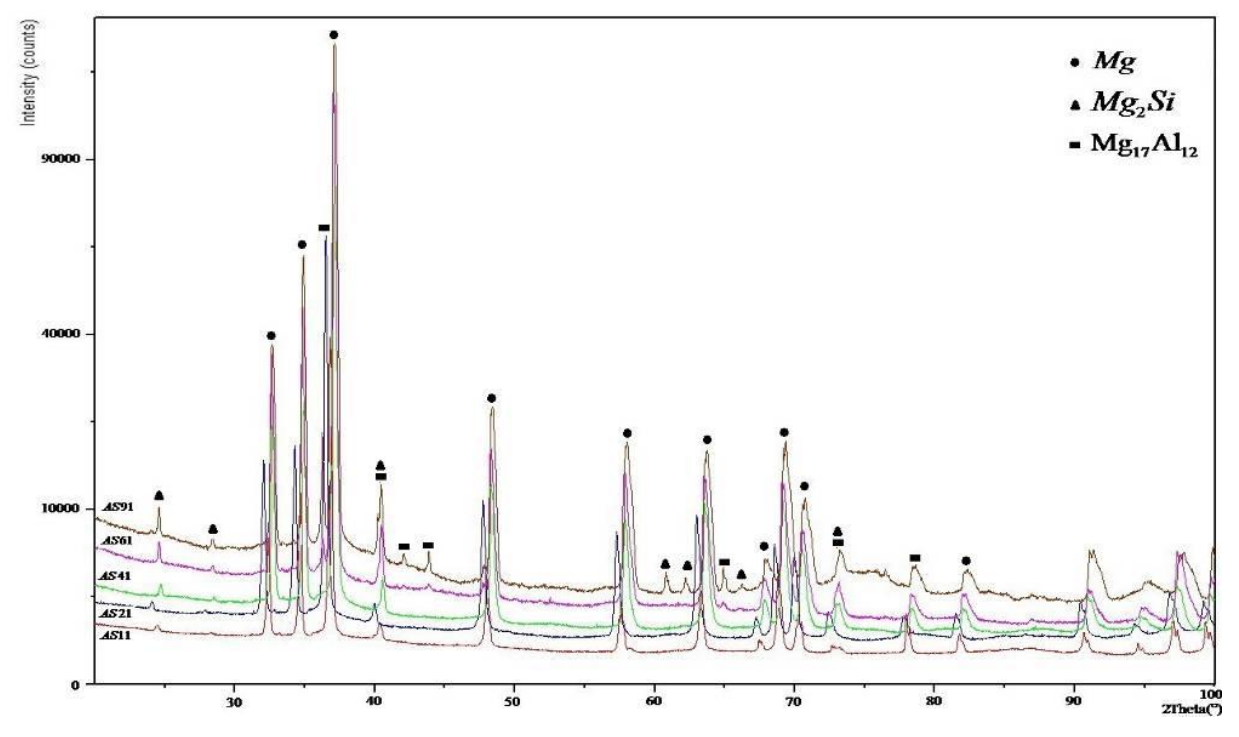

Figure 2. XRD patterns of the alloys.

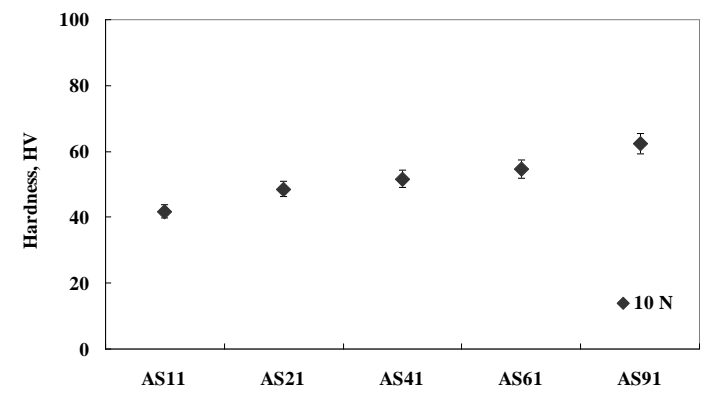

Figure 3. Hardness of the Alloys

\section{B. Density and Thermal Properties}

The densities (seen in Figure 4) and thermal properties (thermal diffusivity and thermal conductivity) (seen in Figure 5a-b) of the alloys varied according to the Al content. The densities of the alloys increased with increasing the Al content in the alloy (seen in Figure 4). The highest density was acquired from the AS91 alloy while the lowest density was detected in the AS11. The densities of these alloys are $1.75 \mathrm{~g} \mathrm{~cm}^{-3}$ in the AS11 alloy and $1.79 \mathrm{~g} \mathrm{~cm}^{-3}$ in the AS91 alloy, which increase starting from AS11 up to AS91 (Figure 4). 


\begin{tabular}{|c|c|c|}
\hline & $\begin{array}{l}\text { BŞEÜ Fen Bilimleri Dergisi } \\
8(1), 109-115,2021\end{array}$ & $\begin{array}{r}\text { BSEU Journal of Science } \\
\text { https://doi.org/10.35193/bseufbd.843874 }\end{array}$ \\
\hline $\begin{array}{l}\text { - BILECIKEYYH EDEE } \\
\text { ONIVERSITE }\end{array}$ & & 2458-7575 (https://dergipark.org.tr/tr/pub/bseufbd) \\
\hline
\end{tabular}

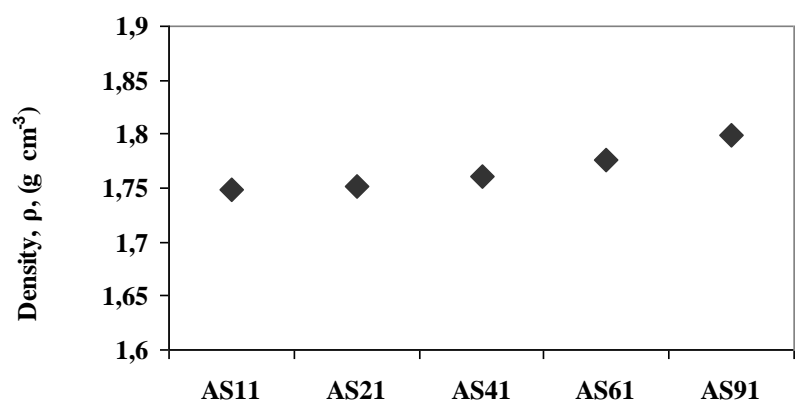

Figure 4. Density of the alloys

Figure 5(a-b) shows the effect of microstructure variations on the thermal properties of the alloys as a function of the alloy content. Thermal diffusivity and thermal conductivity of the $\mathrm{Mg}$ alloys used in the test were observed to decrease as the $\mathrm{Al}$ content (wt.\%) in the alloy increased. Thermal properties of these alloys (except for AS11) increased by increasing temperature. As is known from the literature, thermal properties of pure metals are higher than those of alloys [30,31]. Depending on the temperature increase (from $25^{\circ} \mathrm{C}$ to $400^{\circ} \mathrm{C}$ ) in these alloys, thermal diffusivity and thermal conductivity were observed to increase (Figure 5a-b). While the highest thermal diffusivity and thermal conductivity (at all temperatures) occurred in the AS11 alloy, the lowest thermal properties (at all temperatures) were observed in the AS91 alloy (seen in Figure 5a-b). Considering the thermal diffusivity data of the alloys (from AS11 to AS91) at $25^{\circ} \mathrm{C}$, the thermal diffusivity values of these alloys were $68.4 \mathrm{~mm}^{2} \mathrm{~s}^{-1}, 57.34 \mathrm{~mm}^{2} \mathrm{~s}^{-1}, 44.56 \mathrm{~mm}^{2} \mathrm{~s}^{-1}, 34.81 \mathrm{~mm}^{2} \mathrm{~s}^{-1}$ and $29.33 \mathrm{~mm}^{2} \mathrm{~s}^{-1}$, respectively (seen in Figure 5a). When the temperature was increased to $400{ }^{\circ} \mathrm{C}$, thermal diffusivity values were measured as $65.27 \mathrm{~mm}^{2} \mathrm{~s}^{-1}, 60.72$ $\mathrm{mm}^{2} \mathrm{~s}^{-1}, 49.68 \mathrm{~mm}^{2} \mathrm{~s}^{-1}, 44.14 \mathrm{~mm}^{2} \mathrm{~s}^{-1}$ and $40.47 \mathrm{~mm}^{2} \mathrm{~s}^{-1}$, respectively (seen in Figure $6 \mathrm{a}$ ). The thermal conductivity values of these alloys were $119.54 \mathrm{~W} \mathrm{~m}^{-1} \mathrm{~K}^{-1}, 100.35 \mathrm{~W} \mathrm{~m}^{-1} \mathrm{~K}^{-1}, 78.39 \mathrm{~W} \mathrm{~m}^{-1} \mathrm{~K}^{-1}, 61.79 \mathrm{~W} \mathrm{~m}^{-1} \mathrm{~K}^{-1}$ and $52.56 \mathrm{Wm}^{-}$ ${ }^{1} \mathrm{~K}^{-1}$ at $25^{\circ} \mathrm{C}$, respectively (seen in Figure 5b). When the temperature was increased to $400{ }^{\circ} \mathrm{C}$, thermal conductivity values were measured as $114.07 \mathrm{~W} \mathrm{~m}^{-1} \mathrm{~K}^{-1}, 106.27 \mathrm{~W} \mathrm{~m}^{-1} \mathrm{~K}^{-1}, 87.40 \mathrm{~W} \mathrm{~m}^{-1} \mathrm{~K}^{-1}, 78.35 \mathrm{~W} \mathrm{~m}^{-1} \mathrm{~K}^{-1}$ and $72.53 \mathrm{~W} \mathrm{~m}$ ${ }^{1} \mathrm{~K}^{-1}$, respectively (seen in Figure 5b). The thermal properties of AS series cast $\mathrm{Mg}$ alloys increased depending on the temperature (from $25^{\circ} \mathrm{C}$ to $400^{\circ} \mathrm{C}$ ) (seen in Figure 5). On the other hand, thermal diffusivity and thermal conductivity decreased with increasing $\mathrm{Al}$ content (seen in Figure 5).
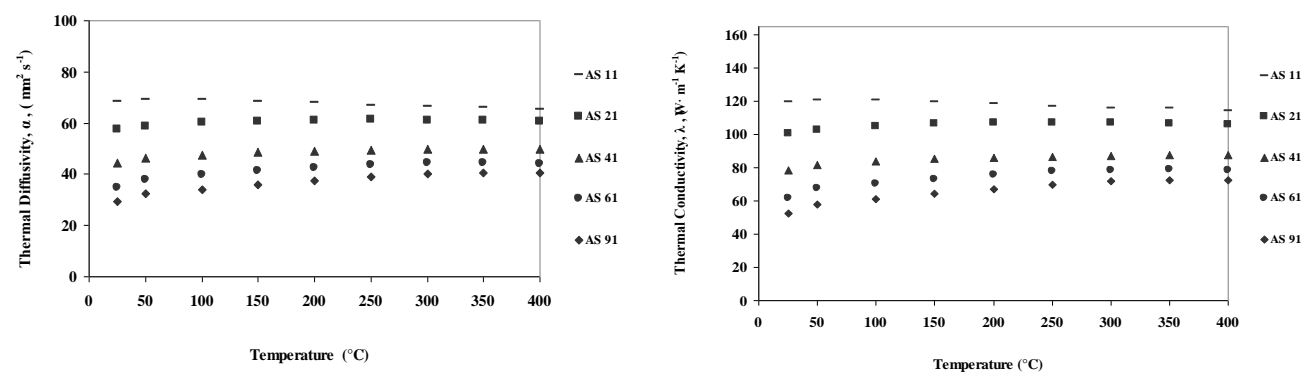

Figure 5. (a) Thermal diffusivity and (b) thermal conductivity of the alloys.

This experimental study results show that the intermetallic phases found $\left(\mathrm{Mg}_{17} \mathrm{Al}_{12}\right.$ and $\left.\mathrm{Mg}_{2} \mathrm{Si}\right)$ in microstructure of AS series magnesium alloys could be very effective on density, thermal properties (thermal diffusivity and thermal conductivity) and hardness as well. Results obtained from the study are in agreement with the literature [5,6,8,9,11,12,23-25,28-31]. 


\section{CONCLUSIONS}

The following results were obtained as a result of this experimental study:

- The alloy composition (from 1 to $9 \mathrm{Al}$ and constant $1 \mathrm{Si}$, wt.\%) has an effect on the place and shape of intermetallic phases $\left(\mathrm{Mg}_{17} \mathrm{Al}_{12}\right.$ and $\left.\mathrm{Mg}_{2} \mathrm{Si}\right)$ in the microstructure of AS series cast $\mathrm{Mg}$ alloys. The intermetallic phases in the alloys are effective on density and thermal properties/behaviors.

- The densities and thermal properties of the alloys vary according to the $\mathrm{Al}$ content (and constant $\mathrm{Si}$ ). The densities of the alloys increase with increasing $\mathrm{Al}$ content. While the highest density was observed in the AS91 alloy $\left(1.79 \mathrm{~g} \mathrm{~cm}^{-3}\right)$, the lowest density was in the AS11 $\left(1.75 \mathrm{~g} \mathrm{~cm}^{-3}\right)$.

- Thermal properties/behaviors of the alloys were observed to decrease with increasing $\mathrm{Al}$ content (wt.\%) in the alloy. Depending on the increase in temperature in the alloys (from $25^{\circ} \mathrm{C}$ to $400^{\circ} \mathrm{C}$ ), thermal diffusivity and thermal conductivity were observed to increase (except for AS11). While the highest thermal properties (at all temperatures) occurred in the AS21 alloy, the lowest thermal properties (at all temperatures) were observed in the AS91 alloy (Figure 6a-b).

- We may conclude that the $\mathrm{Mg}$ alloy components affect the alloy microstructure $\left(\mathrm{Mg}_{2} \mathrm{Si}\right.$ and $\mathrm{Mg}_{17} \mathrm{Al}_{12}$ intermetallic phases) and thermal properties; they also have an effect on temperature increase at the cutting tool tip, FBU occurs/accelerates at the cutting tool tip, wear occurs at the cutting tip and chip lengths vary, thereby facilitating ignition and burning.

\section{ACKNOWLEDGEMENTS}

The author would like to thank to Bilecik Şeyh Edebali University for support (2016-02.BŞEÜ.03-02 and 2018-02.BŞEÜ.03-03).

\section{REFERENCES}

[1] Friedrich, H.E., Mordike, B.L. (2006). Magnesium Technology. Springer-Verlag Berlin Heidelberg, Germany.

[2] Mehta, D. S., Masood, S. H., Song, W. Q. (2004). Investigation of wear properties of magnesium and aluminum alloys for automotive applications. Journal of Materials Processing Technology, 155-156; 15261531.

[3] Tönshoff, H. K., Denkena, B., Winkler, R. J., Podolsky, C. (2006). Machining, magnesium technology, metallurgy, design data, applications. Verlag Berlin Heidelberg: Springer, 398

[4] Srinivasan, A., Ajithkumar, K. K., Swaminathan, J., Pillai, U. T. S., \& Pai, B. C. (2013). Creep behavior of AZ91 magnesium alloy. Procedia Engineering, 55, 109-113.

[5] Li-jie, C., Guo-rui, M., Chun-chong, T. (2012). Effects of isothermal process parameters on semisolid microstructure of Mg-8\% Al-1\% Si alloy. Transactions of Nonferrous Metals Society of China, 22(10), 23642369.

[6] Ünal, M. (2008). An investigation of casting properties of magnesium alloys, Gazi University, Institute of Science And Technology, Ph.D. Thesis.

[7] Srinivasan, A., Swaminathan, J., Pillai, U. T. S., Guguloth, K., Pai, B. C. (2008). Effect of combined addition of $\mathrm{Si}$ and $\mathrm{Sb}$ on the microstructure and creep properties of AZ91 magnesium alloy. Materials Science and Engineering: A, 485(1-2), 86-91.

[8] Li, X. L., Chen, Y. B., \& Xiang, W. (2010). Effect of cooling rates on as-cast microstructures of Mg-9Al-xSi $(\mathrm{x}=1,3)$ alloys. Transactions of nonferrous metals society of China, 20, s393-s396.

[9] Srinivasan, A., Swaminathan, J., Gunjan, M. K., Pillai, U. T. S., Pai, B. C. (2010). Effect of intermetallic phases on the creep behavior of AZ91 magnesium alloy. Materials Science and Engineering: A, 527(6), 1395-1403.

[10] Akyüz, B., (2013). Influence of Al content on machinability of AZ series Mg alloys. Transactions of Nonferrous Metals Society of China, 23(8), 2243-2249.

[11] Ma, G.R., Li, X. L., Xiao, L., Li, Q. F. (2010). Effect of holding temperature on microstructure of an AS91 alloy during semisolid isothermal heat treatment. Journal of Alloys and Compounds, 496(1-2), 577-581.

[12] Dargusch, M. S., Dunlop, G. L., Bowles, A. L., Pettersen, K., Bakke, P. (2004). The effect of silicon content on the microstructure and creep behavior in die-cast magnesium AS alloys. Metallurgical and Materials 
Transactions A, 35(6), 1905-1909.

[13] Tomac, N., Tønnessen, K., Mikac, T. (2008). Study of influence of aluminium content on machinability of magnesium alloys. Strojarstvo: časopis za teoriju i praksu u strojarstvu, 50(6), 363-367.

[14] Zhao, X. L., Tang, Y., Deng, W. J., Zhang, F. Y. (2007). Effect of tool flank wear on the orthogonal cutting process. In Key Engineering Materials (Vol. 329, pp. 705-710). Trans Tech Publications Ltd.

[15] Tönshoff, H. K., Winkler, J. (1997). The influence of tool coatings in machining of magnesium. Surface and Coatings Technology, 94, 610-616.

[16] Tönshoff, H. K., Friemuth, T., Winkler, J., Podolsky, C. (2000). Improving the characteristics of magnesium workpieces by burnishing operations. Magnesium alloys and their applications, 406-411.

[17] Liu, K., Li, X. P., Liang, S. Y. (2007). The mechanism of ductile chip formation in cutting of brittle materials. The International Journal of Advanced Manufacturing Technology, 33(9-10), 875-884.

[18] Ünal, M. (2014). Effects of solidification rate and Sb additions on microstructure and mechanical properties of as cast AM60 magnesium alloys. International Journal of Cast Metals Research, 27(2), 80-86.

[19] Faruk, M., Özdemir, A., Kainer, K.U., Norbert, H. (2013). Influence of Ce addition on microstructure and mechanical properties of high pressure die cast AM50 magnesium alloy. Transactions of Nonferrous Metals Society of China, 23(1), 66-72.

[20] Tsuchiya, T., Watanabe, K., Matsuda, K., Kawabata, T., Sakakibara, K., Yamaguchi, T., Ikeno, S. (2012). Effect of $\mathrm{Al}$ and $\mathrm{Mn}$ contents on microstructure in AM-series magnesium alloys. In Advanced Materials Research (Vol. 409, pp. 379-382). Trans Tech Publications Ltd.

[21] Kiełbus, A., Sozańska, M., Ciżek, L. (2006). Microstructural Characterisation of AZ91 Magnesium Alloy. In Magnesium: Proceedings of the 6th International Conference-Magnesium Alloys and Their Applications (p. 190). John Wiley \& Sons.

[22] Ma, Y., Zhang, J., Yang, M. (2009). Research on microstructure and alloy phases of AM50 magnesium alloy. Journal of Alloys and Compounds, 470(1-2), 515-521.

[23] Akyüz, B. (2014). Influence of aluminum content on machinability of AS series cast magnesium alloys. Transactions of Nonferrous Metals Society of China, 24(11), 3452-3458.

[24] Akyüz, B. (2014). Comparison of the machinability and wear properties of magnesium alloys. The International Journal of Advanced Manufacturing Technology, 75(9-12), 1735-1742.

[25] Akyüz, B. (2016). Wear and machinability properties of AS series magnesium alloys. Proceedings of the Institution of Mechanical Engineers, Part B: Journal of Engineering Manufacture, 230(4), 701-709.

[26] Akyüz, B. (2014). A study on wear and machinability of AZ series (AZ01-AZ91) cast magnesium alloys. Kovove Mater, 52, 255-262.

[27] Akyüz, B. (2011). Machinability of magnesium and its alloys. TOJSAT: The Online Journal of Science and Technology, 1(3), 31-38.

[28] Lee, S., Ham, H. J., Kwon, S. Y., Kim, S. W., Suh, C. M. (2013). Thermal conductivity of magnesium alloys in the temperature range from $-125{ }^{\circ} \mathrm{C}$ to $400{ }^{\circ} \mathrm{C}$. International Journal of Thermophysics, 34(12), 23432350.

[29] Rudajevová, A., Lukáč, P. (2005). Comparison of the thermal properties of AM20 and AS21 magnesium alloys. Materials Science and Engineering: A, 397(1-2), 16-21.

[30] Chunming, W., Yungui, C., Sufen, X., Wucheng, D., Xia, L. (2013). Thermal conductivity and mechanical properties of as-cast Mg-3Zn-(0.5 3.5) Sn alloys. Rare Metal Materials and Engineering, 42(10), 20192022.

[31] Tritt, T.M. (2005). Thermal conductivity: theory, properties, and applications. Springer Science \& Business Media, 290. 